\title{
Suzuki-Miyaura Cross-Coupling Reactions for Increasing the Efficiency of Tris-Heteroleptic Iridium(III) Emitters
}

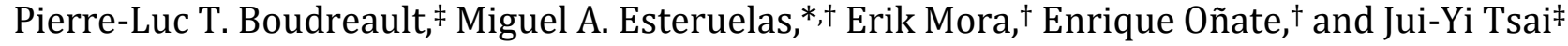 \\ †Departamento de Química Inorgánica, Instituto de Síntesis Química y Catálisis Homogénea (ISQCH), Centro de \\ Innovación en Química Avanzada (ORFEO-CINQA), Universidad de Zaragoza-CSIC, 50009 Zaragoza, Spain \\ *Universal Display Corporation, 375 Phillips Boulevard, Ewing, New Jersey 08618, United States
}

ABSTRACT: Complex $\operatorname{Ir}(\mathrm{acac})\left\{\kappa^{2}-C, N-\left[\mathrm{C}_{6} \mathrm{BrH}_{3}-\mathrm{py}\right]\right\}\left\{\kappa^{2}-\mathrm{C}, N-\left[\mathrm{C}_{6} \mathrm{H}_{4}\right.\right.$-py] $\}$ (2) is a green emitter, which displays short lifetimes (0.9-4.9 $\mu \mathrm{s}$ ) and quantum yields of 0.32 in poly(methyl methacrylate) films at 5 wt \% and of 0.41 in 2 -methyltetrahydrofuran at room temperature. Its $\mathrm{Pd}\left(\mathrm{PPh}_{3}\right)_{4}$-catalyzed cross-coupling reactions with $\mathrm{RB}(\mathrm{OH})_{2}$ afford $\operatorname{Ir}(\mathrm{acac})\left\{\kappa^{2}-C, N-\left[\mathrm{C}_{6} \mathrm{RH}_{3}-\mathrm{py}\right]\right\}\left\{\kappa^{2}-C, N-\left[\mathrm{C}_{6} \mathrm{H}_{4}-\mathrm{py}\right]\right\}(\mathrm{R}$ = Me (3), $\mathrm{Ph}(4))$, which show almost identical emissions with quantum yields in the range 0.98-0.82.

Phosphorescent iridium(III) complexes are positioned at the forefront of modern photochemistry. ${ }^{1}$ The HOMO of compounds of this class bearing cyclometalated 2phenylpyridine ligands mainly comprises the metal $d$ orbitals and the phenyl $\pi$ orbitals, whereas the LUMO is mainly comprised of the $\pi^{*}$ orbitals on the pyridyl rings. Thus, the substituents at 2-phenylpyridine play a critical role in the HOMO-LUMO gap and, as a consequence, in the photophysical properties of the complexes. ${ }^{2}$ In addition, the steric hindrance of substituents at phenyl group disposed in ortho-position with regard to the pyridyl appears to fine-tune their electronic effects, ${ }^{3}$ although ligands with this substitution pattern have been rarely used. ${ }^{4}$

The coordination of different cyclometalated 2phenylpyridines to a metal center is of noticeable interest, since it allows a better govern of the emitter's properties. However, the preparation in moderated yield of neutral $\left[3 b+3 b^{\prime}+3 b^{\prime \prime}\right]$ tris-heteroleptic compounds of iridium(III) with two different orthometalated 2-phenylpyridines and a third ligand, usually acetylacetonate (acac), is certainly a true challenge. This is because the one-pot procedures lead to statistical mixtures of ligands distribution products, ${ }^{5}$ which usually afford the target emitter with a maximum yield of about $30 \%$, and the sequential coordination of the different ligands needs several steps ${ }^{6}$ and has only a relative success when the three ligands are of very different nature; for instance, cyclometalated phenylpyridine, cyclometalated carbene, and acac. ${ }^{7}$ Accordingly, the development of procedures that selectively give these emitters is of great relevance. Although the formation of mixtures of products resulting of distribution reactions of the ligands coordinated to the metal center of trisheteroleptic emitters is favored in solution from a thermodynamically point of view, the emitters are kinetically inert. Thus, once isolated, they rarely evolve into mixtures. In this context, it should be mentioned that six-coordinate iridium(III) complexes exhibit a high octahedral $\Delta_{0}$ splitting. The electron configuration of the $5 \mathrm{~d}^{6}$ metal center is always of low-spin and maximizes the ligand-field stabilization energy. ${ }^{8}$ This fact does pure iridium(III) emitters inert towards the substitution reactions, which are essential to the ligands distribution.

Suzuki-Miyaura cross-coupling reactions are powerful tools for forming carbon-carbon bonds ${ }^{9}$ (eq 1) with broad applications in the preparation of pharmaceuticals, 10 agrochemicals, ${ }^{11}$ and other fine chemicals, ${ }^{12}$ as well as in the total synthesis of natural products. ${ }^{13}$ The search for new materials is also not alien to their value.14 Starting from iridium(III) complexes containing cyclometalated 2phenylpyridine or related ligands, these reactions have been successfully employed in the preparation of emissive polymers ${ }^{15}$ and dendrimers. ${ }^{16}$ The Freixa's group has used this procedure to append azobenzene moieties to the phenyl group, in order to study the effect that the extended conjugation and substitution pattern has on the photochromic behavior of the azobenzene-appended 2-phenylpyridine ligands. ${ }^{17}$ The postfunctionalization of the $3 b^{\prime}$ and $4 b$ ligands of $\left[3 b+3 b+3 b^{\prime}\right]$ and $[3 b+3 b+4 b]+$ iridium(III) complexes has been also reported by several research groups. ${ }^{18}$ In addition, Williams and coworkers have constructed multimetallic broad-band light emitters, by means of the assembly of mononuclear bisterpyridyl complexes with extended conjugation. ${ }^{19}$ A common fact of the performed reactions is the formation of the new carbon-carbon bonds at positions sterically non hindered.

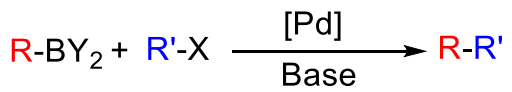

We some months ago showed that the dimers $\left[\operatorname{Ir}(\mu-\mathrm{Cl})\left(\eta^{2}-\right.\right.$ $\left.\left.\mathrm{C}_{8} \mathrm{H}_{14}\right)_{2}\right]_{2}$ and $\left[\operatorname{Ir}(\mu-\mathrm{Cl})\left(\eta^{4}-\mathrm{C}_{8} \mathrm{H}_{12}\right)\right]_{2}$ activate ortho-C-H and ortho-C-Br bonds of the phenyl group of 2-(2bromophenyl)pyridine in a competitive manner. The selectivity of the reactions is governed by the olefin of the starting complex and the experimental conditions. The cyclooctene dimer (1) promotes both ruptures in the same extension, in 2-ethoxyethanol, at $135^{\circ} \mathrm{C}$. As a consequence, the tris-heteroleptic iridium(III) complex $\operatorname{Ir}(\mathrm{acac})\left\{\kappa^{2}-\mathrm{C}, N-\left[\mathrm{C}_{6} \mathrm{BrH}_{3}-\right.\right.$ py] $\left\{\left\{\kappa^{2}-C, N-\left[\mathrm{C}_{6} \mathrm{H}_{4}-\right.\right.\right.$ py $\left.]\right\}(2)$ with two different cyclometalated 2- 


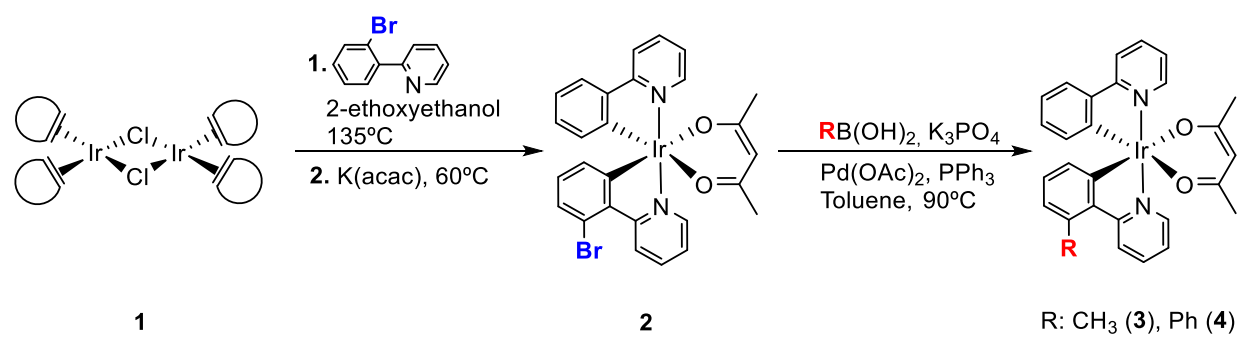

phenylpyridines, one of them with the phenyl group brominated at ortho position with regard to the pyridyl ring, is selectively formed in high yield $(82 \%)^{20}$ (Scheme 1). Although the post-functionalization by Suzuki-Miyaura cross-coupling of that bromine position is sterically hindered and has been not described for this class of compounds, we decided to try it because of several reasons. The success should mean a synthetic procedure of reasonable yield for the preparation of $\left[3 b+3 b^{\prime}+3 b^{\prime \prime}\right]$ tris-heteroleptic iridium(III) complexes. The new compounds would be furthermore the first bearing a cyclometalated 2-phenylpyridine with the phenyl group ortho substituted with regard to the pyridyl. In addition, the formation of these species should allow us to study the influence of the substituents at this elusive position on the photophysical properties of phosphorescent tris-heteroleptic iridium(III) emitters.

The cross-coupling reactions were performed in toluene, at $90^{\circ} \mathrm{C}$. Under these conditions, the treatment of $2^{21}$ with $4.0 \mathrm{~mol}$ of $\mathrm{RB}(\mathrm{OH})_{2}$ and $4.0 \mathrm{~mol}$ of $\mathrm{K}_{3} \mathrm{PO}_{4}$, in the presence of $\mathrm{Pd}\left(\mathrm{PPh}_{3}\right)_{4}$ (10 mol \%), for $24 \mathrm{~h}$ quantitatively gives the corresponding tris-heteroleptic complexes $\operatorname{Ir}($ acac $)\left\{\kappa^{2}-C, N-\left[\mathrm{C}_{6} \mathrm{RH}_{3}-\right.\right.$ py $\left.]\right\}\left\{\kappa^{2-}\right.$ $C, N-\left[\mathrm{C}_{6} \mathrm{H}_{4}\right.$-py]\} (R = Me (3), Ph (4)), which were isolated after column chromatography as pure yellow solids in about $60 \%$ with regard to the starting dimer $\mathbf{1}$; i.e., twice the expected one for the usual one-pot procedure. Both compounds were characterized by X-ray diffraction analysis. Figure 1 shows a view of the structures, which prove the formation of the desired complexes. The geometry around the metal centers is the expected octahedron with the pyridyl groups situated mutually trans.

Data of UV/vis spectra of $1.0 \times \quad 10^{-5} \quad \mathrm{M} \quad 2-$ methyltetrahydrofuran (2-MeTHF) solutions of $\mathbf{2 - 4}$, at room temperature, are collected in Table S1. The spectra of the three compounds are very similar showing bands in three different zones of energy (Figures S5-S7): 220-240, 320-470, and greater than $470 \mathrm{~nm}$, in agreement with other tris-heteroleptic iridium(III) emitters. ${ }^{5-7,22}$ The respective transitions were assigned on the base of the results of time-dependent density functional theory calculations (B3LYP-GD3//SDD(f)/6-31G**) computed in tetrahydrofuran. Absorptions at the highestenergy region are due to $1 \pi-\pi^{*}$ intraligand transitions. The region of moderate energy contains three main bands due to spin-allowed metal-to-phenylpyridine charge transfers (1MLCT) mixed with ligand-to-ligand transitions: 346 (Ir-to$\mathrm{C}_{6} \mathrm{RH}_{3}-$ py), 372-384 (Ir+acac-to- $\mathrm{C}_{6} \mathrm{RH}_{3}-\mathrm{py}+\mathrm{C}_{6} \mathrm{H}_{4}-$ py), and 438468 ( $\mathrm{Ir}+\mathrm{C}_{6} \mathrm{H}_{4}$-py-to- $\mathrm{C}_{6} \mathrm{RH}_{3}$-py) nm. The weak absorption tails after $470 \mathrm{~nm}$ are assigned to formally spin-forbidden ${ }^{3}$ MLCT transitions, produced by the large spin-orbit coupling induced by iridium.

The electrochemical properties of 2-4 were studied using cyclic voltammetry in degassed dichloromethane (2) or acetonitrile ( 3 and $\mathbf{4}$ ) solutions and referenced versus $\mathrm{Fc} / \mathrm{Fc}^{+}$. The three compounds show a one-electron oxidation between 0.48 and $0.39 \mathrm{~V}$ (Table 1 ), whereas no reduction peaks were observed within the solvent window. The computed HOMOLUMO gap of about $3.6 \mathrm{eV}$ is similar to that found for complexes $\operatorname{Ir}$ (acac) $\left\{\kappa^{2}-C, C-\left[\mathrm{C}_{6} \mathrm{H}_{4}-\mathrm{ImMe}\right]\right\}\left\{\kappa^{2}-C, N-\left[\mathrm{C}_{6} \mathrm{R}_{2} \mathrm{H}_{2}-\right.\right.$ py $\left.]\right\}(\mathrm{R}=\mathrm{H}, \mathrm{F})$, which have neither reduction peak and display a similar oxidation at $0.36(\mathrm{R}=\mathrm{H})$ and $0.51(\mathrm{R}=\mathrm{F}) \mathrm{V}^{7}$

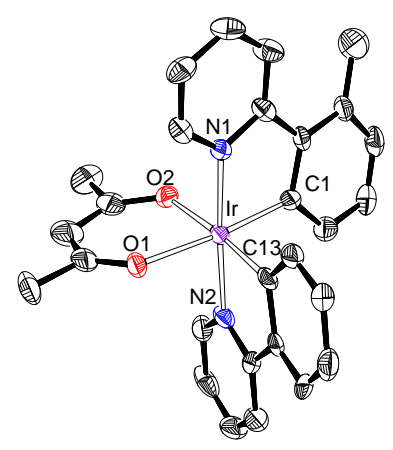

3

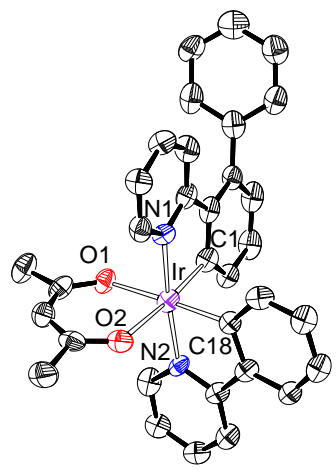

4
Figure 1. ORTEP diagrams of complexes 3 and $4 \quad(50 \%$ probability ellipsoids). Hydrogen atoms are omitted for clarity. Selected bond lengths $(\AA)$ and angles (deg): for 3: $\operatorname{Ir}-\mathrm{N}(1)=$ $2.022(7), \operatorname{Ir}-\mathrm{N}(2)=2.042(7), \operatorname{Ir}-\mathrm{O}(1)=2.143(6), \operatorname{Ir}-\mathrm{O}(2)=$ 2.147(7), Ir-C(1) = 1.987(9), Ir-C(13) = 1.977(10), N(1)-Ir-N(2) $=176.5(3), \mathrm{O}(1)-\mathrm{Ir}-\mathrm{C}(1)=175.0(3), \mathrm{O}(2)-\mathrm{Ir}-\mathrm{C}(13)=174.9(3)$. For 4: $\operatorname{Ir}-\mathrm{N}(1)=2.021(7), \operatorname{Ir}-\mathrm{N}(2)=2.039(8), \operatorname{Ir}-\mathrm{O}(1)=2.136(7)$, $\operatorname{Ir}-\mathrm{O}(2)=2.152(7), \operatorname{Ir}-\mathrm{C}(1)=1.985(10), \operatorname{Ir}-\mathrm{C}(18)=1.988(9)$, $\mathrm{N}(1)-\operatorname{Ir}-\mathrm{N}(2)=174.9(3), \mathrm{O}(1)-\operatorname{Ir}-\mathrm{C}(18)=176.7(3), \mathrm{O}(2)-\mathrm{Ir}-\mathrm{C}(1)$ $=174.8(3)$

Table 1. Electrochemical and DFT Molecular Orbital Energy Data for Complexes 2-4

\begin{tabular}{|l|l|l|l|l|}
\hline Complex & $\begin{array}{l}\mathrm{E}_{1 / 2^{\mathrm{ox}}} \\
\mathrm{a}(\mathrm{V})\end{array}$ & $\begin{array}{l}\mathrm{HOMO}^{\mathrm{b}} \\
(\mathrm{eV})\end{array}$ & LUMO $^{\mathrm{b}}(\mathrm{eV})$ & $\begin{array}{l}\mathrm{HLG}^{\mathrm{b}, \mathrm{c}} \\
(\mathrm{eV})\end{array}$ \\
\hline $\mathbf{2}$ & 0.48 & -5.08 & -1.49 & 3.59 \\
\hline $\mathbf{3}$ & 0.39 & -4.94 & -1.32 & 3.62 \\
\hline $\mathbf{4}$ & 0.42 & -4.98 & -1.37 & 3.61 \\
\hline
\end{tabular}

aMeasured in degassed dichloromethane (2) and acetonitrile $(3,4)$ solutions $\left(1 \times 10^{-3} \mathrm{M}\right) /\left[\mathrm{Bu}_{4} \mathrm{~N}\right] \mathrm{PF}_{6}(0.1 \mathrm{M})$, vs $\mathrm{Fc} / \mathrm{Fc}^{+}$at $0.1 \mathrm{~V} / \mathrm{s}$, at room temperature. bValues from the electronic structures DFT calculations. ${ }^{\mathrm{c} H L G}=$ LUMO $-\mathrm{HOMO}$.

Complexes 2-4 are emissive in the green spectral region upon photoexcitation, in doped poly(methyl methacrylate) (PMMA) $5 \mathrm{wt} \%$ at room temperature and in 2-MeTHF at room temperature and $77 \mathrm{~K}$. The substituent of the phenyl group has not any influence on the color. Thus, the spectra of the three compounds are almost identical. This is consistent with the previously mentioned very similar HOMO-LUMO gaps, since the emissions can be attributed to $\mathrm{T}_{1}$ excited states originated 
by charge transfer transitions between these orbitals. According to this, good agreement is observed between the experimental wavelengths and those calculated by estimating the difference in energy between the optimized triplet state and the singlet state $\mathrm{S}_{0}$, in tetrahydrofuran (Table 2). The emission spectra in PMMA films and in 2-MeTHF at room temperature show broad structureless bands centered at about $528 \mathrm{~nm}$, whereas the spectra in 2-MeTHF at $77 \mathrm{~K}$ display vibronic fine structures with peaks at about 511, 548, and 595 $\mathrm{nm}$, in a consistent manner with the contribution of ligandcentered ${ }^{3} \pi-\pi^{*}$ transitions to the excited state. The lifetimes are short, laying in the range $0.4-5.5 \mu \mathrm{s}$. In contrast to the emission, the quantum yield is substituent dependent; the replacement of the bromide of 2 , which displays similar quantum yield to $\operatorname{Ir}($ acac $)\left\{\kappa^{2}-C, N-\left[\mathrm{C}_{6} \mathrm{H}_{4}-\text { py }\right]\right\}_{2} \quad\left(\lambda_{\mathrm{em}}=516 \mathrm{~nm}, \phi=0.34\right.$ in 2MeTHF), ${ }^{23}$ by methyl or phenyl increases between two and three times the efficiency of the emitter. Thus, complexes $\mathbf{3}$ and 4 display quantum yields close to the unity, in the range 0.98 0.82, in both doped PMMA films and 2-MeTHF at room temperature. We note a similar effect in $\operatorname{Ir}($ acac $)\left\{\kappa^{2}-C, N\right.$ $\left[\mathrm{C}_{6} \mathrm{RH}_{3}-\text { py] }\right\}_{2 .}{ }^{24}$ However, in contrast to $\mathbf{3}$ and $\mathbf{4}$, the incorporation of a phenyl or methyl group at the same pyridine position in $\operatorname{Ir}\left\{\kappa^{2}-C, N-\left[\mathrm{C}_{6} \mathrm{H}_{4}-\text { py }\right]\right\}_{3}$ produces a significant decrease of the emission quantum yield. ${ }^{3}$

In conclusion, the ability of the dimer $\left[\operatorname{Ir}(\mu-\mathrm{Cl})\left(\eta^{2}-\mathrm{C}_{8} \mathrm{H}_{14}\right)_{2}\right]_{2}$ to induce the ruptures ortho- $\mathrm{C}-\mathrm{H}$ and ortho- $\mathrm{C}-\mathrm{Br}$ in the phenyl group of 2-(2-bromophenyl)pyridine, in the same extension, provide a tris-heteroleptic iridium(III) green phosphorescent emitter, with two different orthometalated 2-phenylpyridines; one of them with a bromide at the phenyl in ortho-position with regard to the pyridyl. Without affecting its emission, this emitter increases its efficiency, between two and three times, through the replacement of the bromide by a hydrocarbon fragment, by means of Suzuki-Miyaura cross-coupling reactions. From a methodological point of view, it is also noteworthy the high efficiency of the synthetic procedure that provides the new tris-heteroleptic emitters with a total yield of about $60 \%$. Furthermore, it should be mentioned that the study of the photophysical properties of these emitters has revealed that the substituents at the phenyl in ortho-position to the pyridyl determine the quantum yield of the emission but not its color.

\section{ASSOCIATED CONTENT}

\section{Supporting Information}

The Supporting Information is available free of charge on the ACS Publications website.

Experimental section, structural analysis, computational details, NMR spectra, experimental and computed UV/vis spectra, frontier molecular orbitals, normalized excitation and emission spectra, cyclic voltammograms, $\mathrm{T}_{1}$ and $\mathrm{T}_{2}$ spin densities figures and natural transition orbital analysis. (PDF). Cartesian coordinates of the optimized structure (XYZ).

\section{Accession Codes}

CCDC 1916399-1916400 contain the supplementary crystallographic data for this paper. These data can be obtained free of charge via www.ccdc.cam.ac.uk/data_request/cif, or by emailing data_request@ccdc.cam.ac.uk, or by contacting The Cambridge Crystallographic Data Centre, 12 Union Road, Cambridge CB2 1EZ, UK; fax: +44 1223336033.

\section{AUTHOR INFORMATION}

\section{Corresponding Author}

*E-mail for M.A.E.: maester@unizar.es.

\section{ORCID}

Miguel A. Esteruelas: 0000-0002-4829-7590

Erik Mora: 0000-0001-9585-3011

Enrique Oñate: 0000-0003-2094-719X

Jui-Yi Tsai: 0000-0002-8516-9985

Notes

The authors declare no competing financial interest.

\section{ACKNOWLEDGMENT}

Financial support from the MINECO of Spain (Projects CTQ2017-82935-P and Red de Excelencia Consolider CTQ2016-81797-REDC), the Diputación General de Aragón (Group E06_17R and project LMP148_18), FEDER, and the European Social Fund is acknowledged.

Table 2. Photophysical Data for Complexes 2-4

\begin{tabular}{|l|l|l|l|l|l|l|l|l|l|}
\hline Complex & Calcd $\lambda_{\mathrm{em}}{ }^{\mathrm{a}}(\mathrm{nm})$ & Media (T,K) & $\lambda_{\mathrm{em}}(\mathrm{nm})$ & $\lambda_{\mathrm{ex}}(\mathrm{nm})$ & $\tau(\mu \mathrm{s})$ & $\phi$ & $\mathrm{k}_{\mathrm{r}}^{\mathrm{b}}\left(\mathrm{s}^{-1}\right)$ & $\mathrm{k}_{\mathrm{nr}}^{\mathrm{b}}\left(\mathrm{s}^{-1}\right)$ & $\mathrm{k}_{\mathrm{r}} / \mathrm{k}_{\mathrm{nr}}$ \\
\hline $\mathbf{2}$ & \multirow{3}{*}{531} & PMMA(298) & 527 & 470 & 0.4 & 0.32 & $9.0 \times 10^{5}$ & $1.9 \times 10^{6}$ & 0.47 \\
& & 2-MeTHF (298) & 528 & 469 & 1.0 & 0.41 & $3.9 \times 10^{5}$ & $5.6 \times 10^{5}$ & 0.70 \\
& & 2-MeTHF (77) & $511,548,596$ & 470 & 5.6 & & & \\
\hline $\mathbf{3}$ & \multirow{2}{*}{525} & PMMA(298) & 526 & 472 & 0.9 & 0.82 & $9.4 \times 10^{5}$ & $2.1 \times 10^{5}$ & 4.6 \\
& & 2-MeTHF (298) & 527 & 471 & 1.8 & 0.86 & $4.8 \times 10^{5}$ & $7.9 \times 10^{4}$ & 6.1 \\
& & 2-MeTHF (77) & $509,547,594$ & 472 & 4.9 & & & \\
\hline $\mathbf{4}$ & \multirow{2}{*}{530} & PMMA(298) & 529 & 470 & 0.6 & 0.84 & $1.4 \times 10^{6}$ & $2.7 \times 10^{5}$ & 5.2 \\
& & 2-MeTHF (298) & 529 & 470 & 1.7 & 0.98 & $5.6 \times 10^{5}$ & $1.2 \times 10^{4}$ & 49.0 \\
& & 2-MeTHF (77) & $512,550,597$ & 471 & 5.4 & & & \\
\hline
\end{tabular}

aPredicted from TD-DFT calculations in THF at $298 \mathrm{~K}$. bCalculated according to the equations $\mathrm{k}_{\mathrm{r}}=\phi / \tau$ and $\mathrm{k}_{\mathrm{nr}}=(1-\phi) / \tau$, where $\mathrm{k}_{\mathrm{r}}$ is the radiative rate constant, $\mathrm{knn}_{\mathrm{nr}}$ is the nonradiative rate constant, $\phi$ is the quantum yield, and $\tau$ is the excited-state lifetime 


\section{REFERENCES}

(1) (a) You, Y.; Nam, W. Photofunctional triplet excited states of cyclometalated $\operatorname{Ir}(\mathrm{III})$ complexes: beyond electroluminescence. Chem. Soc. Rev. 2012, 41, 7061-7084. (b) Omae, I. Application of the five-membered ring blue light-emitting iridium products of cyclometalation reactions as OLEDs. Coord. Chem. Rev. 2016, 310 154-169. (c) Kapturkiewicz, A. Cyclometalated iridium(III) chelates-a new exceptional class of the electrochemiluminescent luminophores. Anal. Bioanal. Chem. 2016, 408, 7013-7033. (d) Chi, Y.; Chang, T.-K.; Ganesan, P.; Rajakannu, P. Emissive bis-tridentate Ir(III) metal complexes: Tactics, photophysics and applications. Coord. Chem. Rev. 2017, 346, 91-100.

(2) (a) Ragni, R.; Orselli, E.; Kottas, G. S.; Omar, O. H.; Babudri, F.; Pedone, A.; Naso, F.; Farinola, G. M.; De Cola, L. Iridium(III) Complexes with Sulfonyl and Fluorine Substituents: Synthesis, Stereochemistry and Effect of Functionalisation on their Photophysical Properties. Chem. Eur. J. 2009, 15, 136-148. (b) Baranoff, E.; Curchod, B. F. E.; Monti, F.; Steimer, F.; Accorsi, G.; Tavernelli, I.; Rothlisberger, U.; Scopelliti, R.; Grätzel, M.; Nazeeruddin, M. K. Influence of halogen atoms on a homologous series of bis-cyclometalated iridium(III) complexes. Inorg. Chem. 2012, 51, 799-811. (c) Frey, J.; Curchod, B. F. E.; Scopelliti, R.; Tavernelli, I.; Rothlisberger, U.; Nazeeruddin, M. K.; Baranoff, E. Structure-property relationships based on Hammett constants in cyclometalated iridium(III) complexes: their application to the design of a fluorine-free FIrPic-like emitter. Dalton Trans. 2014, 43 , 5667-5679. (d) Zhang, Q.; Zhao, L.; Han, D.; Zhang, G. Theoretical investigation on the electronic structures and photophysical properties of a series of iridium(III) complexes with different main ligands. Chem. Phys. Lett. 2015, 633, 35-40. (e) Esteruelas, M. A.; López, A. M.; Oñate, E.; San-Torcuato, A.; Tsai, J. -Y.; Xia, C. Preparation of Phosphorescent Iridium(III) Complexes with a Dianionic C,C,C,C-Tetradentate Ligand. Inorg. Chem. 2018, 57, 3720-3730.

(3) Kim, J.-H.; Kim, S.-Y.; Cho, D. W.; Son, H.-J.; Kang, S. O. Influence of bulky substituents on the photophysical properties of homoleptic iridium(III) complexes. Phys. Chem. Chem. Phys. 2019, 21, 6908-6916.

(4) (a) Velusamy, M.; Thomas, K. R. J.; Chen, C.-H.; Lin, J. T.; Wen, Y. S.; Hsieh, W.-T.; Lai, C.-H.; Chou, P.-T. Synthesis, structure and electroluminescent properties of cyclometalated iridium complexes possessing sterically hindered ligands. Dalton Trans. 2007, 3025-3034. (b) Huang, C.; Zhen, C.-G.; Su, S. P.; Chen, Z.-K.; Liu, X.; Zou, D.-C.; Shi, Y.-R.; Loh, K. P. High-efficiency solution processable electrophosphorescent iridium complexes bearing polyphenylphenyl dendron ligands. J. Organomet. Chem. 2009, 694, 1317-1324. (c) Lee, K. H.; Kang, H. J.; Lee, S. J.; Kim, Y. K.; Yoon, S. S. Efficient red phosphorescent iridium complexes for organic lightemitting diodes based on 5-benzoyl-2-phenylpyridine ligands with fluorine and methyl moieties. Synth. Met. 2012, 162, 715-721. (d) King, S. M.; Claire, S.; Teixeira, R. I.; Dosumu, A. N.; Carrod, A. J.; Dehghani, H.; Hannon, M. J.; Ward, A. D.; Bicknell, R.; Botchway, S. W.; Hodges, N. J.; Pikramenou, Z. Iridium Nanoparticles for Multichannel Luminescence Lifetime Imaging, Mapping Localization in Live Cancer Cells. J. Am. Chem. Soc. 2018, 140, 10242-10249.

(5) (a) Baranoff, E.; Curchod, B. F. E.; Frey, J.; Scopelliti, R.; Kessler, F.; Tavernelli, I.; Rothlisberger, U.; Grätzel, M.; Nazeeruddin, M. K. Acid-Induced Degradation of Phosphorescent Dopants for OLEDs and Its Application to the Synthesis of Trisheteroleptic Iridium(III) Bis-cyclometalated Complexes. Inorg. Chem. 2012, 51, 215-224. (b) Lepeltier, M.; Graff, B.; Lalevée, J.; Wantz, G.; Ibrahim-Ouali, M.; Gigmes, D.; Dumur, F. Heteroleptic iridium (III) complexes with three different ligands: Unusual triplet emitters for light-emitting electrochemical cells. Org. Electron. 2016, 37, 24-34. (c) Cudré, Y.; Franco De Carvalho, F.; Burgess, G. R.; Male, L.; Pope, S. J. A.; Tavernelli, I.; Baranoff, E. Trisheteroleptic Iridium Complexes Based on Cyclometalated Ligands with Different Cores. Inorg. Chem. 2017, 56, 11565-11576.

(6) (a) Tamura, Y.; Hisamatsu, Y.; Kumar, S.; Itoh, T.; Sato, K.; Kuroda, R.; Aoki, S. Efficient Synthesis of Tris-Heteroleptic
Iridium(III) Complexes Based on the $\mathrm{Zn}^{2+}$-Promoted Degradation of Tris-Cyclometalated Iridium(III) Complexes and Their Photophysical Properties. Inorg. Chem. 2017, 56, 812-833. (b) Tamura, Y.; Hisamatsu, Y.; Kazama, A.; Yoza, K.; Sato, K.; Kuroda, R.; Aoki, S. Stereospecific Synthesis of Tris-heteroleptic Triscyclometalated Iridium(III) Complexes via Different Heteroleptic Halogen-Bridged Iridium(III) Dimers and Their Photophysical Properties. Inorg. Chem. 2018, 57, 4571-4589.

(7) Adamovich, V.; Bajo, S.; Boudreault, P.-L. T.; Esteruelas, M. A.; López, A. M.; Martín, J.; Oliván, M.; Oñate, E.; Palacios, A. U.; SanTorcuato, A.; Tsai, J.-Y.; Xia, C. Preparation of Tris-Heteroleptic Iridium(III) Complexes Containing a Cyclometalated Aryl-NHeterocyclic Carbene Ligand. Inorg. Chem. 2018, 57, 10744-10760.

(8) Atwood, J. D. Inorganic and Organometallic Reaction Mechanisms; VCH Publishers: New York, 1997; Chapter 3.

(9) (a) Miyaura, N.; Yamada, K.; Suzuki, A. New Stereospecific Cross-Coupling by the Palladium-Catalyzed Reaction of 1Alkenylboranes with 1-Alkenyl or 1-Alkynyl Halides. Tetrahedron Lett. 1979, 20, 3437-3440. (b) Miyaura, N.; Suzuki, A. PalladiumCatalyzed Cross-Coupling Reactions of Organoboron Compounds. Chem. Rev. 1995, 95, 2457-2483.

(10) Magano, J.; Dunetz, J. R. Large-Scale Applications of Transition Metal-Catalyzed Couplings for the Synthesis of Pharmaceuticals. Chem. Rev. 2011, 111, 2177-2250.

(11) Devendar, P.; Qu, R.-Y.; Kang, W.-M.; He, B.; Yang, G.-F. Palladium-Catalyzed Cross-Coupling Reactions: A Powerful Tool for the Synthesis of Agrochemicals. J. Agr. Food Chem. 2018, 66, 8914-8934.

(12) Torborg, C.; Beller, M. Recent Applications of PalladiumCatalyzed Coupling Reactions in the Pharmaceutical, Agrochemical, and Fine Chemical Industries. Adv. Synth. Catal. 2009, 351, 3027-3043.

(13) (a) Deore, P. S.; Argade, N. P. Metal-Catalyzed CrossCoupling Reactions of Halomaleic Anhydrides and Halomaleimides: Synthesis of Structurally Interesting and Biologically Important Natural and Unnatural Products. Synthesis 2014, 46, 281-289. (b) Taheri Kal Koshvandi, A.; Heravi, M. M.; Momeni, T. Current Applications of Suzuki-Miyaura Coupling Reaction in The Total Synthesis of Natural Products: An update. Appl. Organomet. Chem. 2018, 32, e4210.

(14) (a) Fan, Y.; Zhao, J.; Yan, Q.; Chen, P. R.; Zhao, D. WaterSoluble Triscyclometalated Organoiridium Complex: Phosphorescent Nanoparticle Formation, Nonlinear Optics, and Application for Cell Imaging. ACS Appl. Mater. Interfaces 2014, 6, 3122-3131. (b) Xu, S.; Kim, E. H.; Wei, A.; Negishi, E.-i. Pd- and Nicatalyzed cross-coupling reactions in the synthesis of organic electronic materials. Sci. Technol. Adv. Mater. 2014, 15, 044201. (c) He, K.; Wang, X.; Yu, J.; Jiang, H.; Xie, G.; Tan, H.; Liu, Y.; Ma, D.; Wang, Y.; Zhu, W. Synthesis and optoelectronic properties of novel fluorene-bridged dinuclear cyclometalated iridium (III) complex with A-D-A framework in the single-emissive-layer WOLEDs. Org. Electron. 2014, 15, 2942-2949. (d) Huang, Z.; Liu, B.; He, Y.; Yan, X. G.; Yang, X. L.; Xu, X. B.; Zhou, G. J.; Ren, Y. X.; Wu, Z. X. Facilitating triplet energy-transfer in polymetallayne-based phosphorescent polymers with iridium(III) units and the great potential in achieving high electroluminescent performances. J. Organomet. Chem. 2015, 794, 1-10.

(15) (a) Schulz, G. L.; Holdcroft, S. Conjugated Polymers Bearing Iridium Complexes for Triplet Photovoltaic Devices. Chem. Mater 2008, 20, 5351-5355. (b) Yan, Q.; Yue, K.; Yu, C.; Zhao, D. Oligo- and Polyfluorene-Tethered $f a c$-Ir(ppy) $)_{3}$ Substitution Effects. Macromolecules 2010, 43, 8479-8487. (c) Guo, T.; Guan, R.; Zou, J.; Liu, J.; Ying, L.; Yang, W.; Wu, H.; Cao, Y. Red light-emitting hyperbranched fluorene-alt-carbazole copolymers with an iridium complex as the core. Polym. Chem. 2011, 2, 2193-2203. (d) Guo, T.; Yu, L.; Zhao, B.; Li, Y.; Tao, Y.; Yang, W.; Hou, Q.; Wu, H.; Cao, Y. Highly Efficient, Red-Emitting Hyperbranched Polymers Utilizing a Phenyl-Isoquinoline Iridium Complex as the Core. Macromol. Chem. Phys. 2012, 213, 820-828. (e) Hohenleutner, A.; Schmidbauer, S.; Vasold, R.; Joosten, D.; Stoessel, P.; Buchholz, H.; König, B. Rapid Combinatorial Synthesis and Chromatography Based Screening of Phosphorescent Iridium Complexes for Solution Processing. Adv. 
Funct. Mater. 2012, 22, 3406-3413. (f) Liang, A.-H.; Zhang, K.; Zhang, J.; Huang, F.; Zhu, X.-H.; Cao, Y. Supramolecular Phosphorescent Polymer Iridium Complexes for High-Efficiency Organic Light-Emitting Diodes. Chem. Mater. 2013, 25, 1013-1019. (g) Lian, M.; Yu, Y.; Zhao, J.; Huang, Z.; Yang, X.; Zhou, G.; Wu, Z.; Wang, D. Novel phosphorescent polymers containing both ambipolar segments and functionalized IrIII phosphorescent moieties: synthesis, photophysical, redox, and electrophosphorescence investigation. J. Mater. Chem. C. 2014, 2, 9523-9535. (h) Guo, T.; Yu, L.; Yang, Y.; Li, Y.; Tao, Y.; Hou, Q.; Ying, L.; Yang, W.; Wu, H.; Cao, Y. Hyperbranched red light-emitting phosphorescent polymers based on iridium complex as the core. J. Lumin. 2015, 167, 179-185.

(16) (a) Lai, W.-Y.; Levell, J. W.; Jackson, A. C.; Lo, S.-C.; Bernhardt, P. V.; Samuel, I. D. W.; Burn, P. L. A Phosphorescent Poly(dendrimer) Containing Iridium(III) Complexes: Synthesis and Light-Emitting Properties. Macromolecules 2010, 43, 69866994. (b) Stoltzfus, D. M.; Jiang, W.; Brewer, A. M.; Burn, P. L. Twisted dendrons for highly luminescent green emissive phosphorescent dendrimers. J. Mater. Chem. C. 2018, 6, 1031510326.

(17) (a) Pérez-Miqueo, J.; Telleria, A.; Muñoz-Olasagasti, M.; Altube, A.; García-Lecina, E.; de Cózar, A.; Freixa, Z. Azobenzenefunctionalized iridium(III) triscyclometalated complexes. Dalton Trans. 2015, 44, 2075-2091. (b) Pérez-Miqueo, J.; Altube, A.; García-Lecina, E.; Tron, A.; McClenaghan, N. D.; Freixa, Z. Photoswitchable azobenzene-appended iridium(III) complexes. Dalton Trans. 2016, 45, 13726-13741.

(18) (a) Davidson, R.; Hsu, Y.-T.; Bhagani, C.; Yufit, D.; Beeby, A. Exploring the Chemistry and Photophysics of Substituted Picolinates Positional Isomers in Iridium(III) Bisphenylpyridine Complexes. Organometallics 2017, 36, 2727-2735. (b) Hisamatsu, Y.; Kumar, S.; Aoki, S. Design and Synthesis of Tris-Heteroleptic Cyclometalated Iridium(III) Complexes Consisting of Three Different Nonsymmetric Ligands Based on Ligand-Selective Electrophilic Reactions via Interligand HOMO Hopping Phenomena. Inorg. Chem. 2017, 56, 886-899. (c) Kataoka, Y.; Okuno, K.; Yano, N.; Ueda, H.; Kawamoto, T.; Handa, M. New luminescent cyclometalated iridium complexes prepared by the post-synthetic modification. J. Photoch. Photobio. A. 2018, 358, 345-355. (d) Davidson, R. J.; Hsu, Y. T.; Yufit, D.; Beeby, A. Emission Tuning of $\operatorname{Ir}\left(\mathrm{N}^{\wedge} \mathrm{C}\right)_{2}$ (pic)-Based Complexes via Torsional Twisting of Picolinate Substituents. Organometallics 2018, 37, 2003-2006.
(19) (a) Leslie, W.; Batsanov, A. S.; Howard, J. A. K.; Williams, J. A. G. Cross-couplings in the elaboration of luminescent bisterpyridyl iridium complexes: the effect of extended or inhibited conjugation on emission. Dalton Trans. 2004, 623-631. (b) Whittle, V. L.; Williams, J. A. G. A New Class of Iridium Complexes Suitable for Stepwise Incorporation into Linear Assemblies: Synthesis, Electrochemistry, and Luminescence. Inorg. Chem. 2008, 47, 65966607. (c) Whittle, V. L.; Williams, J. A. G. Cyclometallated, bisterdentate iridium complexes as linearly expandable cores for the construction of multimetallic assemblies. Dalton Trans. 2009, 3929-3940. (d) Muñoz-Rodríguez, R.; Buñuel, E.; Fuentes, N.; Williams, J. A. G.; Cárdenas, D. J. A heterotrimetallic Ir(III), Au(III) and Pt(II) complex incorporating cyclometallating bi- and tridentate ligands: simultaneous emission from different luminescent metal centres leads to broad-band light emission. Dalton Trans. 2015, 44, 8394-8405. (e) Knuckey, K. J.; Williams, J. A. G. Photon Funnels for One-Way Energy Transfer: Multimetallic Assemblies Incorporating Cyclometallated Iridium or Rhodium Units Accessed by Sequential Cross-Coupling and Bromination. Eur. J. Inorg. Chem. 2017, 5205-5214.

(20) Boudreault, P.-L. T.; Esteruelas, M. A.; Mora, E.; Oñate, E.; Tsai, J.-Y. Pyridyl-Directed $\mathrm{C}-\mathrm{H}$ and $\mathrm{C}-\mathrm{Br}$ Bond Activations Promoted by Dimer Iridium-Olefin Complexes. Organometallics 2018, 37, 3770-3779.

(21) The mixture resulting from the reaction of 1 with 2-(2bromophenyl)pyridine and $\mathrm{K}$ (acac) was directly used as source of 2.

(22) (a) Esteruelas, M. A.; Oñate, E.; Palacios, A. U. Selective Synthesis and Photophysical Properties of Phosphorescent Heteroleptic Iridium(III) Complexes with Two Different Bidentate Groups and Two Different Monodentate Ligands. Organometallics 2017, 36, 1743-1755. (b) Esteruelas, M. A.; Gómez-Bautista, D.; López, A. M.; Oñate, E.; Tsai, J.-Y.; Xia, C. $\eta^{1}$-Arene Complexes as Intermediates in the Preparation of Molecular Phosphorescent Iridium(III) Complexes. Chem. Eur. J. 2017, 23, 15729-15737.

(23) Lamansky, S.; Djurovich, P.; Murphy, D.; Abdel-Razzaq, F.; Kwong, R.; Tsyba, I.; Bortz, M.; Mui, B.; Bau, R.; Thompson, M. E. Synthesis and Characterization of Phosphorescent Cyclometalated Iridium Complexes. Inorg. Chem. 2001, 40, 1704-1711.

(24) Shi, C.; Pan, J.; Yan, X. Organometallic complex, high polymer, mixture, composition and organic electronic device. W02017/092481 A1, 2017 


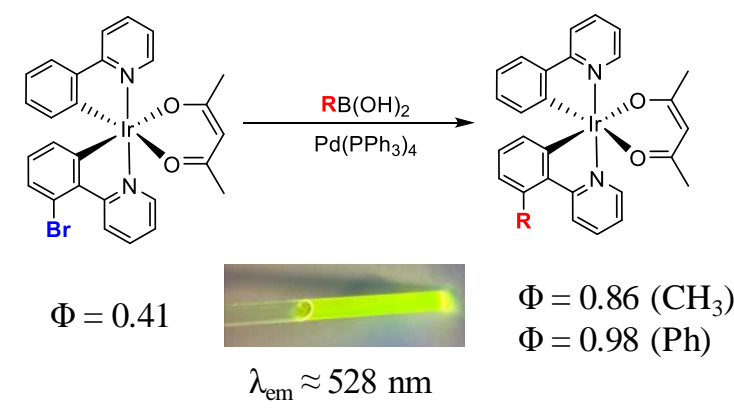

